\title{
Suppression of immunity by some pesticides, xenobiotics, and industrial chemicals. In vitro model
}

\author{
Ilia Brondz ${ }^{1,2^{*}}$, Anton Brondz ${ }^{3}$ \\ ${ }^{1}$ Department of Biology, University of Oslo, Oslo, Norway; " Corresponding Author: ilia.brondz@bio.uio.no, ilia.brondz@gmail.com \\ ${ }^{2} \mathrm{R} \&$ D Department, Jupiter Ltd., Ski, Norway; \\ ${ }^{3}$ Department of Chemistry, Norwegian University of Science and Technology, Trondheim, Norway.
}

Received 20 June 2011; revised 15 July 2011; accepted 22 July 2011.

\section{ABSTRACT}

In recent years, attention has focused on suppression of immunity in immunocompromised patients. The definition of immunocompromise is impairment of the immune system caused by a disease or treatment. In addition to disease and treatment, other factors such as exposure to pesticides or toxic chemicals can damage the immune system. An in vitro test was used to assess the ability of monochloroacetic acid (MCA) (CAS number 79-11-8), dichloroacetic acid (DCA) (CAS number 79-43-6), trichloroacetic acid (TCA) (CAS number 76-03-9), and 2,2-dichloropropionic acid sodium salt (2,2-DCPANa, Dalapon) (CAS number 127-20-8) to suppress bacteriolysis by hen egg white lysozyme (HEWL). The system for bacteriolysis of Gram-negative bacteria Actinobacillus, Haemophilus, and Pasteurella in Tris-maleate buffer supplemented with EDTA and HEWL developed by Brondz et al. [1-4] was used to monitor bacteriolysis of Gramnegative bacteria in the Actinobacillus-Haemophilus-Pasteurella group. The halogenated acetic acid DCA is produced as a toxic artifact of the degradation of TCA and by disinfection of drinking and pool water and industrial waste. Nearly all humans consume DCA in drinking water during their lifetime; the concentration of DCA in drinking water can be higher than that associated with the upper-bound excess lifetime cancer risk of $10^{-4}(40 \mu \mathrm{g} / \mathrm{L})$ [5]. Lysozyme found in tears, saliva, nasal secretions, and excretions from all mucous membranes can break down the cell walls of bacteria and destabilize bacterial membranes. Lysozyme is involved in innate (nonspecific) immunity; the innate immune system is the first line of defense against invading organisms. Actinobacillus actinomycetemcomitans (ATCC29522), a Gram-negative bacterium whose primary ecological niche is the respiratory tract and oral cavity, provided the peptidoglycan substrate for HEWL. The optical density (OD) of a standardized suspension of $A$. actinomycetemcomitans decreased from $100 \%$ (OD 0.6 at $540 \mathrm{~nm}$ ) to $23.5 \%$ after exposure to EDTA/HEWL for $50 \mathrm{~min}$. After $50 \mathrm{~min}$ of exposure to $10.0 \mathrm{mg} / \mathrm{mL}$ of MCA, DCA, TCA, or 2,2-DCPANa as a supplement, EDTA/HEWL-induced lysis of $A$. actinomycetemcomitans decreased to $66.3 \%, 66.8 \%, 65.7 \%$, and $73.6 \%$, respectively. The aim of the presented study was the development of a model for measuring possible immunotoxic effects of chemicals, degradation products, xenobiotics and metabolites by these chemicals on the immune system. The method used is an in vitro bacteriolysis of Gramnegative bacterium induced by HEWL, described previously [1-4]. In the present study, several halogenated acids, MCA, DCA, and TCA, and the $\mathrm{Na}$ salt of 2,2-DCPA, exhibited immunosuppressive activity. The ability of MCA, DCA, TCA, and 2,2-DCPANa (Dalapon) to suppress HEWL induced bacteriolysis was demonstrated in vitro document.

Keywords: Immunosuppression; Immunotoxicity; Chlorinated Aliphatic Acids; Dalapon

\section{INTRODUCTION}

Lysozyme belongs to the innate (nonspecific) immune system; it is a bacteriolytic enzyme that is distributed widely in nature [6] and is found across the entire range of vertebrates and in certain invertebrates, plants, and bacteriophages. In humans, lysozyme found in tears, saliva, nasal secretions, and excretions from all mucous membranes can break down the cell walls of bacteria and destabilize bacterial membranes. Bird egg white is 
particularly rich in lysozyme [7]. Lysozyme is also present in many types of cells including phagocytes, in tissues and organs [8], and in body fluids such as blood and urine.

The natural substrate for lysozyme is peptidoglycan of the bacterial cell wall. Peptidoglycan is a polymer comprising two amino sugars, $\mathrm{N}$-acetylglucosamine and $\mathrm{N}$ acetylmuramic acid, and amino acids. Lysozyme causes hydrolysis of the $\beta(1-4)$ bond between N-acetylmuramic acid and $\mathrm{N}$-acetylglucosamine, resulting in the dissolution of the bacterial cell wall. Lysozyme easily breaks down the cell walls of Gram-positive bacteria in vitro, although some microorganisms, particularly Gram-negative microorganisms, are resistant to lysozyme in vitro. It is likely that lysozyme acts synergistically in vivo with other immune factors such as IgM, IgA (sIgA secetory $\operatorname{IgA} 1$ and $\operatorname{IgA} 2$ ), complement, lactoferrin, or lactoperoxidase, thereby increasing the lytic sensitivity of such organisms [9].

Lysozyme belongs to the innate (nonspecific) immune system, which provides the first line of defense against invading organisms. Lysozyme is also an important part of the adaptive or specific immune system, which works together with the production by phagocytes of toxic oxygen compounds such as the superoxide anion $\left(\mathrm{O}_{2}^{-}\right)$, $\mathrm{H}_{2} \mathrm{O}_{2}$, the singlet oxygen $\left({ }^{1} \mathrm{O}_{2}\right)$, hypochlorite $\left(\mathrm{OCl}^{-}\right)$, and the hydroxyl radical $(\mathrm{OH} \cdot)$ [10]. Lysozyme also stimulates immunoglobulin production [11].

During the last century, many chemicals have been introduced in the biosphere as food additives, herbicides, insecticides, industrial waste and medicines. The array of potential hazards which these chemicals can have to humans is not always clear. The growing number of immunocompromised people together with the adaptation of some microorganisms toward antibiotics has changed the balance between the host organism and a possible pathogen. In the immunocompromised patient, local infections (which are non-threatening for a normal person) can be generalized and cause death.

The method for judging the influence of chemicals on the human immune system in particular and all living creatures in general is needed.

A. actinomycetemcomitans, a Gram-negative bacterium whose primary ecological niche is the respiratory tract and oral cavity, was chosen as the target for lysozyme in this study.

Halogenated acids such as monochloroacetic acid (MCA) (CAS number 79-11-8), dichloroacetic acid (DCA) (CAS number 79-43-6), and trichloroacetic acid (TCA) (CAS number 76-03-9) occur widely in the biosphere as xenobiotics derived from herbicides and pesticides, as artifacts from the disinfection by chlorine of drinking or pool water, and as industrial pollutants
$[5,12,13]$. The broad spectrum of toxicity for humans and animals of MCA, DCA, and TCA is described in $[5,12,13]$. Nearly all humans consume DCA in drinking water throughout the entire lifespan, and the concentration of DCA may exceed that associated with the upper-bound excess lifetime cancer risk of $10^{-4}(40 \mu \mathrm{g} / \mathrm{L})$ [5]. According to the World Health organization (WHO), the tolerable daily intake (TDI) of MCA in drinking water is $20 \mu \mathrm{g} / \mathrm{L}$ [12], and the TDI of TCA is $200 \mu \mathrm{g} / \mathrm{L}$ [13].

Increased hepatocellular carcinomas were observed in male mice given DCA in drinking water [14-16]. The hepato- and immunotoxicity of DCA are described in [17]. Immunotoxicity was characterized as a pronounced response in this investigation. 2,2-Dichloropropionic acid (2,2-DCPA) is a standard herbicide also known as Dowpon, Basinex P, Devipon, Gramevin, Kenapon, Liropon, Dalapon, and Unipon. Because of its selectivity, it kills only certain plants; the major use of Dalapon is on sugarcane and sugar beets [18]. The oral $\mathrm{LD}_{50}$ values range from $3860 \mathrm{mg} / \mathrm{kg}$ for female rabbits to 9330 $\mathrm{mg} / \mathrm{kg}$ for male rats [19]. Dalapon may cause irritation to the mucous membrane linings of the mouth, nose, throat, lungs, and eyes [20].

\section{MATERIALS AND METHODS}

\subsection{Biological Material and Chemicals}

A. actinomycetemcomitans (strain ATCC 29522) was obtained from (American Type Culture Collection, Rockville MD, USA). Stock cultures were kept in liquid nitrogen after reconstitution from the lyophilized state. The bacteria were maintained anaerobically $\left(80 \% \mathrm{~N}_{2}\right.$, $10 \% \mathrm{CO}_{2}$, and $10 \% \mathrm{H}_{2}$ ) on blood agar plates at $35^{\circ} \mathrm{C}$ and were transferred weekly. To measure cell lysis, inoculated blood agar plates were incubated anaerobically for 2 days at $35^{\circ} \mathrm{C}$, and the colonies were transferred on agar slants to preheated $\left(37^{\circ} \mathrm{C}\right)$ Brain Heart Infusion ${ }^{\circledR}$ (Dif$\mathrm{co}^{\mathrm{TM}}$ ) broth (Voigt Global Distribution Inc., USA) and were cultured anaerobically at $35^{\circ} \mathrm{C}$ for 15.5 hours.

\subsection{Lysozyme}

The mucopeptide N-acetylmuramoylhydrolase (muramidase, EC 3.2.1.17; BioChemica; powder (crystalline), activity: 70,000 units $/ \mathrm{mg}, \mathrm{M}_{r} \sim 14.600$ ) was obtained from Sigma-Aldrich (Sigma-Aldrich Norway AS, Oslo, Norway).

\subsection{Halogenated Acids}

MCA, DCA, and TCA were obtained from SigmaAldrich Norway AS, and 2,2-DCPA sodium salt (2,2DCPANa) was obtained from Dow Chemical Co. (Midland, MI, USA). 


\subsection{Ultraviolet-Visible (UV-Vis) Spectrometry}

UV-vis spectrometry was recorded using a Lambda 35 UV-vis spectrometer (PerkinElmer Inc., San Jose, CA, USA) using a quartz colorimetric cell under heated conditions. Spectrometry was recorded in six parallel controls and in six parallel samples for each pesticide added. The measurements were repeated on four separate days. The results for days 1, 2, 3, and 4 are presented in Tables $1,2,3$, and 4 , respectively. The day-to-day variations are presented in Table 5.

\subsection{Assessment of Bacteriolysis}

The sensitivity of $A$. actinomycetemcomitans to EDTA $(0.01 \mathrm{M})$ and hen egg white lysozyme (HEWL) was examined in Tris-maleate buffer $(0.005 \mathrm{M}, \mathrm{pH} 7.2)$ as described previously [1-3]. Briefly, washed bacterial cells were suspended in the buffer, and the optical density (OD) was adjusted to 1.0 at $540 \mathrm{~nm}$ before preincubation for $5 \mathrm{~min}$ in the buffer at $37^{\circ} \mathrm{C}$. The OD was then adjusted to 0.6 , and $20 \mu \mathrm{L}$ of buffer or lysozyme solution was added to the spectrophotometric cells, each containing bacteria suspended in $1.980 \mu \mathrm{L}$ of $0.005 \mathrm{M}$ Trismaleate buffer supplemented with EDTA and one of the halogenated substances at a concentration of $10 \mathrm{mg} / \mathrm{mL}$,

Table 1. Induced lyses of A. actinomycetemcomitans.

\begin{tabular}{|c|c|c|c|}
\hline \multicolumn{4}{|c|}{$\begin{array}{l}\text { Amount of Chemical in } \mathrm{mg} / \mathrm{mL} \text { added to EDTA in Tris-maleate } \\
\text { buffer }+\mathrm{HEWL} 0.1 \mathrm{mg} / \mathrm{mL} 1 \mathrm{mg} / \mathrm{mL} 10 \mathrm{mg} / \mathrm{mL} \text { or Amount of } \\
\text { Chemical in } \mathrm{mM} / \mathrm{mL} \text { added to EDTA in Tris-maleate buffer + } \\
\text { HEWL }\end{array}$} \\
\hline MCA & $1 \mathrm{mM}$ & $10 \mathrm{mM}$ & $100 \mathrm{mM}$ \\
\hline \multicolumn{4}{|c|}{ EDTA in Tris-maleate buffer + HEWL + MCA } \\
\hline & $24.0 *$ & $28.5 *$ & $66.0 *$ \\
\hline DCA & $800 \mu \mathrm{M}$ & $8 \mathrm{mM}$ & $80 \mathrm{mM}$ \\
\hline \multicolumn{4}{|c|}{ EDTA in Tris-maleate buffer + HEWL + DCA } \\
\hline & $24.9 *$ & $29.4 *$ & $67.1 *$ \\
\hline TCA & $600 \mu \mathrm{M}$ & $6 \mathrm{mM}$ & $60 \mathrm{mM}$ \\
\hline \multicolumn{4}{|c|}{ EDTA in Tris-maleate buffer + HEWL + TCA } \\
\hline & $23.9 *$ & $27.8^{*}$ & $65.7 *$ \\
\hline & $600 \mu \mathrm{M}$ & $6 \mathrm{mM}$ & $60 \mathrm{mM}$ \\
\hline \multicolumn{4}{|c|}{ EDTA in Tris-maleate buffer + HEWL $+2,2$-DCPANa } \\
\hline & $27.7 *$ & $38.9 *$ & $73.5^{*}$ \\
\hline
\end{tabular}

Induced lyses of A. actinomycetemcomitans on day 1 were in EDTA in Tris-maleate buffer 61.7, and EDTA in Tris-maleate buffer + HEWL 23.8, $n=$ 6. Optical density measured at $540 \mathrm{~nm}$ in percentage of initial OD after 50 min. * Mean value, $n=6$, the $\mathrm{RSD}=5 \%$.
Table 2. Induced lyses of A. actinomycetemcomitans.

Amount of Chemical in $\mathrm{mg} / \mathrm{mL}$ added to EDTA in Tris-maleate buffer + HEWL $0.1 \mathrm{mg} / \mathrm{mL} 1 \mathrm{mg} / \mathrm{mL} 10 \mathrm{mg} / \mathrm{mL}$ or Amount of Chemical in Amount of Chemical in $\mathrm{mM} / \mathrm{mL}$ added to EDTA in Tris-maleate buffer + HEWL

\begin{tabular}{|c|c|c|c|}
\hline MCA & $1 \mathrm{mM}$ & $10 \mathrm{mM}$ & $100 \mathrm{mM}$ \\
\hline \multicolumn{4}{|c|}{ EDTA in Tris-maleate buffer + HEWL + MCA } \\
\hline & $24.2 *$ & $28.8^{*}$ & $66.1 *$ \\
\hline DCA & $800 \mu \mathrm{M}$ & $8 \mathrm{mM}$ & $80 \mathrm{mM}$ \\
\hline \multicolumn{4}{|c|}{ EDTA in Tris-maleate buffer + HEWL + DCA } \\
\hline & $24.3^{*}$ & $28.9^{*}$ & $66.8^{*}$ \\
\hline TCA & $600 \mu \mathrm{M}$ & $6 \mathrm{mM}$ & $60 \mathrm{mM}$ \\
\hline \multicolumn{4}{|c|}{ EDTA in Tris-maleate buffer + HEWL + TCA } \\
\hline & $23.7 *$ & $27.5^{*}$ & $65.9 *$ \\
\hline 2,2-DCPANa & $600 \mu \mathrm{M}$ & $6 \mathrm{mM}$ & $60 \mathrm{mM}$ \\
\hline \multicolumn{4}{|c|}{ EDTA in Tris-maleate buffer + HEWL $+2,2$-DCPANa } \\
\hline & $27.9^{*}$ & $38.7^{*}$ & $73.9 *$ \\
\hline
\end{tabular}

Induced lyses of A. actinomycetemcomitans on day 2 were in EDTA in Tris-maleate buffer 62.0, and EDTA in Tris-maleate buffer + HEWL 23.5, $n=$ 6 . Optical density measured at $540 \mathrm{~nm}$ in percentage of initial OD after 50 $\min . *$ Mean value, $n=6$, the $\mathrm{RSD}=5 \%$.

Table 3. Induced lyses of A. actinomycetemcomitans.

Amount of Chemical in $\mathrm{mg} / \mathrm{mL}$ added to EDTA in Tris-maleate buffer + HEWL $0.1 \mathrm{mg} / \mathrm{mL} 1 \mathrm{mg} / \mathrm{mL} 10 \mathrm{mg} / \mathrm{mL}$ or Amount of Chemical in $\mathrm{mM} / \mathrm{mL}$ added to EDTA in Tris-maleate buffer + HEWL
MCA
$1 \mathrm{mM}$
$10 \mathrm{mM}$
$100 \mathrm{mM}$

EDTA in Tris-maleate buffer + HEWL + MCA

$\begin{array}{cccc} & 24.5^{*} & 28.9^{*} & 66.7^{*} \\ \text { DCA } & 800 \mu \mathrm{M} & 8 \mathrm{mM} & 80 \mathrm{mM}\end{array}$

EDTA in Tris-maleate buffer + HEWL + DCA

$\begin{array}{cccc} & 24.1^{*} & 28.7^{*} & 67.1^{*} \\ \text { TCA } & 600 \mu \mathrm{M} & 6 \mathrm{mM} & 60 \mathrm{mM}\end{array}$

EDTA in Tris-maleate buffer + HEWL + TCA

$\begin{array}{ccc}23.7^{*} & 27.5^{*} & 65.9^{*} \\ 600 \mu \mathrm{M} & 6 \mathrm{mM} & 60 \mathrm{mM}\end{array}$

EDTA in Tris-maleate buffer + HEWL $+2,2$-DCPANa

$$
\begin{array}{lll}
28.0^{*} & 38.5^{*} & 73.3^{*}
\end{array}
$$

Induced lyses of A. actinomycetemcomitans on day 1 were in EDTA in Tris-maleate buffer 61.9, and EDTA in Tris-maleate buffer + HEWL 23.2, $n=$ 6. Optical density measured at $540 \mathrm{~nm}$ in percentage of initial OD after 50 min. *Mean value, $n=6$, the $\mathrm{RSD}=5 \%$. 
Table 4. Induced lyses of A. actinomycetemcomitans.

Amount of Chemical in $\mathrm{mg} / \mathrm{mL}$ added to EDTA in Tris-maleate buffer + HEWL $0.1 \mathrm{mg} / \mathrm{mL} 1 \mathrm{mg} / \mathrm{mL} 10 \mathrm{mg} / \mathrm{mL}$ or Amount of Chemical in $\mathrm{mM} / \mathrm{mL}$ added to EDTA in Tris-maleate buffer + HEWL

\begin{tabular}{|c|c|c|c|}
\hline MCA & $1 \mathrm{mM}$ & $10 \mathrm{mM}$ & $100 \mathrm{mM}$ \\
\hline \multicolumn{4}{|c|}{ EDTA in Tris-maleate buffer + HEWL + MCA } \\
\hline & $24.2^{*}$ & $28.7^{*}$ & $66.3 *$ \\
\hline DCA & $800 \mu \mathrm{M}$ & $8 \mathrm{mM}$ & $80 \mathrm{mM}$ \\
\hline \multicolumn{4}{|c|}{ EDTA in Tris-maleate buffer + HEWL + DCA } \\
\hline & $24.4^{*}$ & $29.0^{*}$ & $66.8^{*}$ \\
\hline TCA & $600 \mu \mathrm{M}$ & $6 \mathrm{mM}$ & $60 \mathrm{mM}$ \\
\hline \multicolumn{4}{|c|}{ EDTA in Tris-maleate buffer + HEWL + TCA } \\
\hline & $23.8^{*}$ & $27.5^{*}$ & $65.6^{*}$ \\
\hline & $600 \mu \mathrm{M}$ & $6 \mathrm{mM}$ & $60 \mathrm{mM}$ \\
\hline \multicolumn{4}{|c|}{ EDTA in Tris-maleate buffer + HEWL $+2,2$-DCPANa } \\
\hline & $27.9^{*}$ & $38.7^{*}$ & $73.5^{*}$ \\
\hline
\end{tabular}

Induced lyses of A. actinomycetemcomitans on day 1 were in EDTA in Tris-maleate buffer 61.8, and EDTA in Tris-maleate buffer + HEWL 23.5, $n=$ 6. Optical density measured at $540 \mathrm{~nm}$ in percentage of initial OD after 50 min. * Mean value, $n=6$, the $\mathrm{RSD}=5 \%$.

$1.0 \mathrm{mg} / \mathrm{mL}$, or $0.1 \mathrm{mg} / \mathrm{mL}$.

After $50 \mathrm{~min}$ of exposure to MCA, DCA, TCA, or 2,2-DCPANa as a supplement, EDTA/HEWL-induced lyses of A. actinomycetemcomitans were recorded.

\section{RESULTS AND DISCUSSION}

The amounts of chemicals added to EDTA in Trismaleate buffer $+\mathrm{HEWL}$ are expressed in $\mathrm{mg} / \mathrm{mL}$, as often expressed in toxicological studies; for comparison, these values are also expressed in their closest approximations to $\mathrm{mM}$ or $\mu \mathrm{M}$. The OD data are presented in Tables 1-4 respectively. The data presented in Tables 1-4 are the data from measurements on four separate days. The data presented in Table 5 summarize the day-to-day variations.

After exposure of A. actinomycetemcomitans to EDTA for $50 \mathrm{~min}$, the measured OD decreased from $100 \%$ to $61.7 \%, 62.0 \%, 61.9 \%$, and $61.8 \%$, respectively (Tables 1-4).

After exposure of A. actinomycetemcomitans to EDTA/ HEWL for $50 \mathrm{~min}$, the measured OD declined from $100 \%$ to $23.8 \%, 23.5 \%, 23.2 \%$, and $23.5 \%$, respectively (Tables 1-4).

After exposure of A. actinomycetemcomitans to EDTA/ HEWL $+10.0 \mathrm{mg} / \mathrm{mL}$ MCA the OD decreased from $100 \%$ to $66.0 \%, 66.1 \%, 66.7 \%$, and $66.3 \%$, respectively.

After exposure of A. actinomycetemcomitans to EDTA/
Table 5. Induced lyses of A. actinomycetemcomitans day-today performance.

\begin{tabular}{cc}
\hline EDTA in Tris-maleate buffer + HEWL $+10 \mathrm{mg} / \mathrm{mL}$ MCA \\
Mean & Total days 4 \\
Standard deviation & 66.275 \\
& 0.30957
\end{tabular}

EDTA in Tris-maleate buffer + HEWL + $1 \mathrm{mg} / \mathrm{mL}$ MCA

Total days 4

$\begin{array}{cc}\text { Mean } & 28.725 \\ \text { Standard deviation } & 0.17078\end{array}$

EDTA in Tris-maleate buffer + HEWL + 0.1 mg/mL MCA

Total days 4

$\begin{array}{cc}\text { Mean } & 24.225 \\ \text { Standard deviation } & 0.20616\end{array}$

EDTA in Tris-maleate buffer + HEWL $+10 \mathrm{mg} / \mathrm{mL}$ DCA

Total days 4

$\begin{array}{cc}\text { Mean } & 66.8 \\ \text { Standard deviation } & 0.24495\end{array}$

EDTA in Tris-maleate buffer + HEWL + $1 \mathrm{mg} / \mathrm{mL}$ DCA

Total days 4

\begin{tabular}{cc} 
Mean & 29.0 \\
Standard deviation & 0.29439 \\
EDTA in Tris-maleate buffer + HEWL $+0.1 \mathrm{mg} / \mathrm{mL}$ DCA \\
\multicolumn{3}{c}{ Total days 4} \\
Mean & 24.425 \\
Standard deviation & 0.34034 \\
EDTA in Tris-maleate buffer + HEWL $+10 \mathrm{mg} / \mathrm{mL} \mathrm{TCA}$
\end{tabular}

EDTA in Tris-maleate buffer + HEWL $+10 \mathrm{mg} / \mathrm{mL}$ TCA

Total days 4

Mean $\quad 65.65$

Standard deviation $\quad 0.20817$

EDTA in Tris-maleate buffer + HEWL + $1 \mathrm{mg} / \mathrm{mL}$ TCA

Total days 4

$\begin{array}{cc}\text { Mean } & 27.525 \\ \text { Standard deviation } & 0.20616\end{array}$

EDTA in Tris-maleate buffer + HEWL $+0.1 \mathrm{mg} / \mathrm{mL}$ TCA

Total days 4

$\begin{array}{cc}\text { Mean } & 23.825 \\ \text { Standard deviation } & 0.9574\end{array}$

EDTA in Tris-maleate buffer + HEWL + $10 \mathrm{mg} / \mathrm{mL} 2,2-\mathrm{DCPNa}$

Total days 4

$\begin{array}{cc}\text { Mean } & 73.575 \\ \text { Standard deviation } & 0.25\end{array}$

EDTA in Tris-maleate buffer + HEWL + $1 \mathrm{mg} / \mathrm{mL} 2,2-\mathrm{DCPNa}$

Total days 4

Mean $\quad 38.7$

Standard deviation $\quad 0.1633$

EDTA in Tris-maleate buffer $+\mathrm{HEWL}+0.1 \mathrm{mg} / \mathrm{mL} 2,2-\mathrm{DCPNa}$

Total days 4

$\begin{array}{cc}\text { Mean } & 27.875 \\ \text { ndard deviation } & 0.12583\end{array}$

Induced lyses of A. actinomycetemcomitans EDTA in Tris-maleate buffer + HEWL

Total days 4

Mean

23.5

Standard deviation

0.24495 
HEWL $+1.0 \mathrm{mg} / \mathrm{mL}$ MCA the OD declined from $100 \%$ to $28.5 \%, 28.8 \%, 28.9 \%$, and $28.7 \%$, respectively.

After exposure of A. actinomycetemcomitans to EDTA/ $\mathrm{HEWL}+0.1 \mathrm{mg} / \mathrm{mL}$ MCA the OD declined from $100 \%$ to $24.0 \%, 24.2 \%, 24.5 \%$, and $24.2 \%$, respectively.

After exposure of A. actinomycetemcomitans to EDTA/ HEWL $+10.0 \mathrm{mg} / \mathrm{mL}$ DCA the OD decreased from $100 \%$ to $67.1 \%, 66.8 \%, 66.5 \%$, and $66.8 \%$, respectively.

After exposure of A. actinomycetemcomitans to EDTA/ HEWL $+1.0 \mathrm{mg} / \mathrm{mL}$ DCA the OD decreased from $100 \%$ to $29.4 \%, 28.9 \%, 28.7 \%$, and $29.0 \%$, respectively.

After exposure of A. actinomycetemcomitans to EDTA/ HEWL $+0.1 \mathrm{mg} / \mathrm{mL}$ DCA the OD declined from $100 \%$ to $24.9 \%, 24.3 \%, 24.1 \%$, and $24.4 \%$, respectively.

After exposure of A. actinomycetemcomitans to EDTA/ HEWL + $10.0 \mathrm{mg} / \mathrm{mL}$ TCA the OD decreased from $100 \%$ to $65.7 \%, 65.9 \%, 65.4 \%$, and $65.6 \%$, respectively.

After exposure of A. actinomycetemcomitans to EDTA/ HEWL $+1.0 \mathrm{mg} / \mathrm{mL}$ TCA the OD declined from $100 \%$ to $27.8 \%, 27.5 \%, 27.3 \%$, and $27.5 \%$, respectively.

After exposure of A. actinomycetemcomitans to EDTA/ HEWL $+0.1 \mathrm{mg} / \mathrm{mL}$ TCA the OD decreased from $100 \%$ to $23.9 \%, 23.7 \%, 23.9 \%$, and $23.8 \%$, respectively.

After exposure of A. actinomycetemcomitans to EDTA/ HEWL + $10.0 \mathrm{mg} / \mathrm{mL}$ 2,2-DCPANa the OD decreased from $100 \%$ to $73.5 \%, 73.9 \%, 73.3 \%$, and $73.6 \%$, respectively.

After exposure of A. actinomycetemcomitans to EDTA/ HEWL + $1.0 \mathrm{mg} / \mathrm{mL}$ 2,2-DCPANa the OD declined from $100 \%$ to $38.9 \%, 38.7 \%, 38.5 \%$, and $38.7 \%$, respectively.

After exposure of A. actinomycetemcomitans to EDTA/ HEWL + $0.1 \mathrm{mg} / \mathrm{mL}$ 2,2-DCPANa the OD decreased from $100 \%$ to $27.7 \%, 27.9 \%, 28.0 \%$, and $27.9 \%$, respectively.

In the present study, several halogenated acids, MCA, DCA, and TCA, and the Na salt of 2,2-DCPA, exhibited immunosuppressive activity. MCA, DCA, and TCA are usually found in treated drinking or swimming pool water or as a result of the degradation of pesticides and xenobiotics; 2,2-DCPA is a pesticide. These substances exerted marked suppression of the bacteriolytic effect of HEWL on bacterial peptidoglycan in vitro. The mechanisms responsible for this suppression are not known in detail, but enzyme deactivation was not related to acid strength because 2,2-DCPANa had the most potent effects in the experiments, and 2,2-DCPANa was in a salt form, in contrast to the acidic form of MCA, DCA, and TCA. It is possible that chlorinated ions were responsible for the deactivation of HEWL because 2,2-DCPANa exerted the most potent suppressive action.

Most chemical noxae are capable of binding proteins in organisms. TCA has a high capacity for protein bind- ing and probably interacts readily with the basic protein, lysozyme. Iodoacetic acid modifies methionine and lysine situated in the primary structure of lysozyme [21]. It has been suggested that EDTA permits HEWL access to peptidoglycan to initiate autolysis activity in A. actinomycetemcomitans [1-4].

There has been a recent increase in the isolation of facultative anaerobic, Gram-negative rods in clinical samples [22]. This increase cannot be related to improved diagnostic methods alone. In addition to the increased isolation of such organisms, people are being exposed increasingly to halogenated substances in the biosphere [5,12-17]. Farmers and chemical workers, who tend to be exposed most heavily [18-20], have higher rates of chronic bronchitis than do physicians and firemen [23]. Such exposure may predispose to secondary infection by opportunists residing on the nasal, bronchial, and oral mucosa, particularly when important aspects of nonspecific immunity are inhibited. In addition to its industrial and agricultural uses, MCA is often found as a contaminant of TCA and the herbicide Dalapon, in which 2,2-DCPANa is the active ingredient, and in other chemicals such as EDTA. Such contamination may increase the toxicity of the main substance. MCA is also produced as a metabolite of chemicals such as vinylidene chloride, vinyl chloride, 1,1,2-trichloroethane, trichloroethylene, and 1,2-dichloroethane [24-27]. MCA is known to cause severe damage to energy-rich tissues and to interfere with the tricarboxylic acid cycle and gluconeogenesis $[28,29]$. The kinetics of MCA metabolism in adult male rats is described in [30].

DCA is generated as a metabolite after exposure to trichloroethene and as a byproduct of the chlorination of drinking water. The in vivo immunotoxicity of DCA is reported in [17].

TCA tends to accumulate in the organism, where it may counteract the effect of lysozyme. TCA is a metabolite of trichloroethylene (TCE) and perchloroethylene (PCE) and is detectable in the urine of humans exposed to these solvents. TCA has been shown to act as a liver tumor promoter in several studies in which rats or mice were treated with an initiating dose of a carcinogen followed by chronic exposure to TCA in the drinking water.

Dalapon or 2,2-DCPANa is an herbicide and plant growth regulator used to control specific annual and perennial grasses. The major food crop use of Dalapon is on sugarcane and sugar beets [31]. Repeated and/or prolonged exposure to Dalapon may cause irritation of the mucous membrane linings of the mouth, nose, throat, lungs, and eyes [32], and the possible involvement of the kidneys in the death of animals has been described [33]. Its interference with the body's ability to synthesize pro- 
tein and to use sugar from food is described in [34].

Lysozyme deactivation by the halogenated substances did not parallel their acute toxicity. Even when tested at the lowest molar concentration, Dalapon exhibited the highest deactivation potential toward lysozyme in the present study.

It is possible that the substances examined may affect lysozyme in vivo, i.e., those present in organs, tissues, cells, and body fluids such as blood and urine.

Immunotoxicology is a subject of recent interest because the physiology and biochemistry of the immune system and the basic processes involved in host defense mechanisms are now understood better. Successful interfacing between immunology testing and toxicology evaluation of chemicals is still in the early stages. Immunotoxicology assays should be included routinely in the evaluation of chemicals, especially herbicides and pesticides. The present study provides the basis for judging whether chemicals present a potential risk to nonspecific host defense.

\section{CONCLUSIONS}

1) An in vitro model for recording immunosuppressive effect of some chlorinated aliphatic acids on the bacteriolytic effect of HEWL was developed. This effect is general for lysozyme of any origin. Some of the used chemicals are artifacts from chlorination of water.

2) Dalapon exhibited the highest immunosuppressive effect. Enzyme deactivation was not related to acid strength, but instead the chlorinated ions were responsible for the deactivation of HEWL.

3) The immunosuppressive effect by the halogenated substances did not parallel their acute toxicity. Therefore, the acute toxicity and $\mathrm{LD}_{50}$ examination of chemicals should be supplemented with a test for immunosuppressive effectiveness for every chemical halogenated as for non-halogenated.

\section{ACKNOWLEDGEMENTS}

The present study was supported in part by Jupiter Ltd., Norway.

\section{REFERENCES}

[1] Brondz, I. (1985) Chemotaxonomy of selected species of the Actinobacillus-Haemophilus-Pasteurella group by means of gas chromatography, gas chromatography-mass spectrometry and bioenzymatic methods. PhD Thesis, University of Oslo, Oslo.

[2] Brondz, I. and Olsen, I. (1986) (Review) Chemotaxonomy of selected species of the Actinobacillus-Haemophilus-Pasteurella group by means of gas chromatography, gas chromatography-mass spectrometry and bioenzymatic methods. Journal of Chromatography, 380, 1-17.

[3] Olsen, I. and Brondz, I. (1985) Differentiation among closely related organisms of the Actinobacillus-Haemophilus-Pasteurella group by means of lysozyme and EDTA. Journal of Clinical Microbiology, 22, 629-636.

[4] Brondz, I., Olsen, I. and Sjøstrøm, M. (1990) Multivariate analysis of quantitative chemical and enzymatic characterization data in classification of Actinobacillus, Haemophilus and Pasteurella spp. The Journal of General Microbiology, 136, 507-513.

[5] WHO/SDE/WSH/05.08/121 (2005) Dichloroacetic acid in drinking-water, background document for development of WHO guidelines for drinking-water quality. http://www.who.int/water sanitation health/dwq/chemic als/dichloroaceticacid0505.pdf

[6] Johnson, L.N., (1998), The early history of lysozyme. Nature Structural \& Molecular Biology, 5, 942-944. doi:10.1038/2917

[7] Alderton, G., Ward, W. and Febold, H. (1945) Isolation of lysozyme from egg white. The Journal of Biological Chemistry, 157, 43-58.

[8] Kalfa, V.C. and Brogden, K.A. (1999) Anionic antimicrobial peptide-lysozyme interactions in innate pulmonary immunity. International Journal of Antimicrobial Agents, 13, 47-51. doi:10.1016/S0924-8579(99)00095-3

[9] Smékal, F. (1973) Lysis of lyophilized Eschericial coli cell with egg-white lysozyme without ethylenediaminetetr acetic acid. Folia Microbiologica, 18, 146-148.

[10] Thompson, H.L. and Wilton, J.M. (1991) Effects of an aerobiosis and aerobiosis on interactions of human poly morphonuclear leukocytes with the dental plaque bacteria Streptococcus mutans, Capnocytophaga ochracea, and Bacteroides gingivalis. Infection and Immunity, 59, 932-940.

[11] Sugahara, T., Murakami, F., Yoko Yamada, Y. and Sasaki, T. (2000) The mode of actions of lysozyme as an immunoglobulin production stimulating factor. Biochemica et Biophisica Acta, 1475, 27-34.

[12] WHO/SDE/WSH/03.04/85 (2004) Monochloroacetic acid in drinking-water, background document for development of who guidelines for drinking-water quality. http://www.who.int/water_sanitation_health/dwq/chemic als/monochloroaceticacid.pdf

[13] $\overline{\mathrm{WHO} / \mathrm{SDE} / \mathrm{WSH} / 03.04 / 120}$ (2004) Trichloroacetic acid in drinking-water, background document for development of WHO guidelines for drinking-water quality. http://www.who.int/water_sanitation_health/dwq/chemic als/trichloroaceticacid.pdf

[14] Herren-Freund, S.L., Pereira, M.A., Khoury, M.D. and Olson G. (1987) The carcinogenicity of trichloroethylene and its metabolites, trichloroacetic acid and dichloroacetic acid, in mouse liver. Toxicology and Applied Pharmacology, 9, 183-189. doi:10.1016/0041-008X(87)90325-5

[15] Bull, R.J., Orner, G.A., Cheng, R.S., Stillwell, L., Stauber, A.J., Sasser, L.B., Lingohr, M.K. and Thrall, B.D. (2002) Contribution of Dichloroacetate and Trichloroacetate to Liver tumor induction in mice by trichloroethylene. Toxicology and Applied Pharmacology, 182, 55-65. doi:10.1006/taap.2002.9427

[16] Daniel, F.B., DeAngelo, A.B., Stober, J.A., Olson, G.R. and Page, N.P. (1992) Hepatocarcinogenicity of chloral hydrate, 2-chloroacetaldehyde, and dichloroacetic acid in the male B6C3F1 mouse. Fundamental and Applied 
Toxicology, 19, 159-68. doi:10.1016/0272-0590(92)90147-A

[17] Cai, P., Boor, P.J., Khan, M.F., Kaphalia, B.S., Ansari, G.A. and Konig, R. (2007) Immuno- and hepato-toxicity of dichloroacetic acid in $\mathrm{MRL}(+/+)$ and $\mathrm{B}(6) \mathrm{C}(3) \mathrm{F}(1)$ mice. Journal of Immunotoxicology, 4, 107-115. doi:10.1080/15476910701337225

[18] Berg, G.L. (1986) Farm chemicals handbook. Meister Publishing Company, Willoughby.

[19] WSSA Herbicide Handbook Committee (1989) Herbicide handbook of the weed science society of America, 6th Edition, WSSA, Champaign.

[20] Occupational Health Services, Inc. (1986) Material safety data sheet. OHS, Inc., Secaucus.

[21] Jollès, P. (1967) Relationship between chemical structure and biological activity of hen egg-white lysozyme and lysozymes of different species. Proceedings of the Royal Society, 167B, 350-364.

[22] Sakazaki, R., Yoshizaki, E., Tamura, K. and Kuramoch, S. (1984) Increased frequency of isolation of Pasteurella and Actinobacillus species and related organisms. European Journal of Clinical Microbiology \& Infectious Diseases, 3, 244-248. doi:10.1007/BF02014894

[23] Lefcoe, N.M. and Wonnacott, T.H. (1974) Chronic respiretory disease in four occupational groups. Archives of Environmental Health, 29, 143-146.

[24] Yllner, S. (1971) Metabolism of chloroacetate- $1-{ }^{14} \mathrm{C}$ in the mouse. Acta Pharmacologica et Toxicological, 30, 69-80. doi:10.1111/j.1600-0773.1971.tb00635.x

[25] Yllner, S. (1971) Metabolism of 1,1,2-trichloroethane$1,2-{ }^{14} \mathrm{C}$ in the mouse. Acta Pharmacologica et Toxicological, 30, 248-256. doi:10.1111/j.1600-0773.1971.tb00656.x

[26] Bartsch, J., Malaveille, C., Barbin, A., Bresil, H., Tomatis,
L. and Montesano, R. (1976) Mutagenicity and metabolism of vinyl chloride and related compounds. Environmental Health Perspectives, 17, 193-198. doi:10.1289/ehp.7617193

[27] Hathway, D.E. (1977) Comparative mammalian metabolism of vinyl chloride and vinilidene chloride in relation to oncogenic potential. Environmental Health Perspectives, 21, 55-59. doi:10.1289/ehp.772155

[28] Hayes, F.D., Short, R.D. and Gibson, J.E. (1973) Differential toxicity of monochloroacetate, monofluoroacetate and monoiodoacetate in rats. Toxicology and Applied Pharmacology, 26, 93-102. doi:10.1016/0041-008X(73)90089-6

[29] Kulling, P., Anderson, H., Bostrom, K., Johansson, L., Lindstrom, B. and Nystrom, B. (1992) Fatal systemic poisoning after skin exposure to monochloroacetic acid. Clinical Toxicology, 30, 643-652. doi: 10.3109/15563659209017948

[30] Saghir, S.A., Fried, K. and Rozman, K.K. (2001) Kinetics of monochloroacetic acid in adults male rats after intravenouse injection of a subtoxic and a toxic dose. The Journal of Pharmacology and Experimental Therapeutics, 296, 612-622.

[31] Doyle, R. (1984) Dalapon information sheet. Food and Drug Administration, Bureau of Foods, HFF-420.

[32] Occupational Health Services, Inc. (1986) Material safety data sheet. OHS, Inc., Secaucus.

[33] TOXNET (1975-1986) National library of medicine's toxicology data network. Hazardous Substances Data Bank (HSDB). Public Health Service. National Institute of Health, US Department of Health and Human Services. NLM, Bethesda.

[34] Hallenbeck, W.H. and Cunningham-Burns K.M. (1985) Pesticides and human health. Springer-Verlag, Berlin. 